\title{
Article
}

\section{Gold supported on nitrogen-incorporated TS-1 for gas-phase epoxidation of propylene}

\author{
LIU Yiwu a,b, ZHANG Xiaoming a,*, SUO Jishuan ${ }^{a}$ \\ a Chengdu Institute of Organic Chemistry, Chinese Academy of Sciences, Chengdu 610041, Sichuan, China \\ ${ }^{\mathrm{b}}$ College of Chemistry and Chemical Engineering, Neijiang Normal University, Neijiang 641100, Sichuan, China
}

\section{A R T I C L E I N F O}

\section{Article history:}

Received 21 September 2012

Accepted 24 October 2012

Published 20 February 2013

\section{Keywords:}

Gold

Titanium silicalite-1

Epoxidation

Nitridation

Propylene oxide

\begin{abstract}
A B S T R A C T
Nitrogen-incorporated titanium silicalite-1 (NTS-1) was used to prepare a supported gold catalyst for direct gas-phase epoxidation of propylene using $\mathrm{H}_{2}$ and $\mathrm{O}_{2}$. The NTS- 1 was synthesized by direct calcination of the TS-1 powder in a flow of $\mathrm{NH}_{3}$ at high temperature. Gold catalyst supported on NTS-1 was synthesized by the deposition-precipitation method. The samples were characterized by X-ray diffraction, $\mathrm{N}_{2}$ adsorption-desorption, diffuse reflectance ultraviolet-visible spectroscopy, inductively coupled plasma optical emission spectrometry, elemental analysis, X-ray photoelectron spectroscopy, and transmission electron microscopy. The results indicated that nitrogen was incorporated into the TS-1 framework, and that the NTS-1 preserved the multidimensional fatigue inventory (MFI) structure well. It was found that $\mathrm{NH}_{3}$-treatment resulted in decreased acidity of the TS-1 zeolite support and improved both the Au capture efficiency and dispersion, which remarkably improved the catalytic performance. The enhanced activity was ascribed to the decrease in acidic surface sites and the ligand effect of the terminal $\mathrm{NH}_{2}$ groups on the support surface.
\end{abstract}

(C) 2013, Dalian Institute of Chemical Physics, Chinese Academy of Sciences. Published by Elsevier B.V. All rights reserved.

\section{Introduction}

The oxidation of propylene to propylene oxide (PO) using $\mathrm{H}_{2}$ and $\mathrm{O}_{2}$, heterogeneously catalyzed by gold nanoparticles (GNPs), is a highly attractive alternative to conventional PO production processes [1,2]. Numerous investigations have suggested that the nature of the catalyst support plays a crucial role in the catalytic activity and dispersion of the GNPs. The main supports include various Ti-containing materials, such as $\mathrm{TiO}_{2}$, $\mathrm{TiO}_{2} / \mathrm{SiO}_{2}$, TS-1, Ti-MCM-41, Ti-MCM-48, Ti-TUD, etc. [311]. Recent results in the area have shown that the Au catalyst can be improved through modification of the support. Silylation of three-dimensional mesoporous titanosilicate appreciably reduced the number of acidic sites on the support and gave a $\mathrm{PO}$ formation rate of $116 \mathrm{gPO} /\left(\mathrm{h} \cdot \mathrm{kg}_{\mathrm{cat}}\right)$ at $200^{\circ} \mathrm{C}$ [7]. Elimination of acidic surface sites by adding trimethylamine in the reaction stream improved catalyst stability and $\mathrm{H}_{2}$ efficiency [8]. Ge-modified TS- 1 enhanced reactivity because of a ligand effect of the Ge on the Ti centers [10]. Treating TS- 1 with $\mathrm{NH}_{4} \mathrm{NO}_{3}$ before $\mathrm{Au}$ deposition improved the rate to $134 \mathrm{gPO} /\left(\mathrm{h} \cdot \mathrm{kg}_{\mathrm{cat}}\right)$ at $200{ }^{\circ} \mathrm{C}$, because of an increase in the Au content [12]. The main effect of the $\mathrm{NH}_{4} \mathrm{NO}_{3}$ pretreatment was related to an increased number of gold adsorption sites at the Ti-SBA-15 surface [13]. $\mathrm{Au} /$ alkaline-treated TS-1 displayed a high rate of 137 $\mathrm{gPO} /\left(\mathrm{h} \cdot \mathrm{kg}_{\mathrm{cat}}\right)$, which was explained by the alkaline treatment resulting in an increase in the amount of defects in the support [14]. These findings indicated that the reactivity of gold catalysts for propylene epoxidation using $\mathrm{H}_{2}$ and $\mathrm{O}_{2}$ can be improved by decreasing the acidic sites and increasing the amount of defects on the support surface.

Recently, we have successfully prepared a novel nitrogen-incorporated TS-1 zeolite (NTS-1) by calcinating the TS-1

\footnotetext{
* Corresponding author. Tel.: +86-28-85226215; Fax: +86-28-85223978; E-mail: xm.zhang@cioc.ac.cn

This work was supported by the National Natural Science Foundation of China (20703039).

DOI: 10.1016/S1872-2067(11)60474-9 | http://www.sciencedirect.com/science/journal/18722067 | Chin. J. Catal., Vol. 34, No. 2, February 2013
} 
powder in $\mathrm{NH}_{3}$ flow at high temperature $[15,16]$. The acidity of the TS-1 zeolite was effectively decreased by $\mathrm{NH}_{3}$ treatment. The catalyst exhibited high catalytic selectivity and stability for propylene epoxidation with $\mathrm{H}_{2} \mathrm{O}_{2}$. After the 20th run, the N-TS-1-850-5 catalyst (the last two numbers indicate nitridation temperature $\left({ }^{\circ} \mathrm{C}\right)$ and nitridation time (h), respectively) gave a $\mathrm{H}_{2} \mathrm{O}_{2}$ conversion of $91.5 \%$, a $\mathrm{H}_{2} \mathrm{O}_{2}$ selectivity of $92.0 \%$, and a PO selectivity of $90.9 \%$. Nitration of supports could be an effective method for adjusting the surface acidity of the parent supports, while keeping the porous properties. The presence of terminal $\mathrm{NH}_{2}$ groups on the support surface may be propitious for stabilizing metallic nanoparticles. In this study, we found that the nitrogen-incorporated TS-1 was an excellent support for the gold nanoparticle catalyst, which greatly increased both the Au capture efficiency and the dispersion during the deposition-precipitation (DP) process. Moreover, the catalytic activity and stability for the gas-phase epoxidation of propylene with $\mathrm{H}_{2}$ and $\mathrm{O}_{2}$ were remarkably increased.

\section{Experimental}

\subsection{Preparation of supports and catalysts}

TS- 1 supports were synthesized according to the method developed by Khomane et al. [17]. For a typical synthesis, $4.0 \mathrm{~g}$ of Tween 20 was dissolved in a solution of $48 \mathrm{~g}$ of deionized water and $54 \mathrm{~g}$ of tetrapropylammonium hydroxide (TPAOH, 20\%-25\%, TCI). Tetraethylorthosilicate (TEOS, 98\%, Aldrich, $72 \mathrm{~g}$ ) was added drop-wise under vigorous stirring. To this clear solution, a mixture of $1.6 \mathrm{~g}$ of titanium (IV) tetrabutoxide (TBOT, 98\%) dissolved in $10 \mathrm{ml}$ of isopropanol (99.5\%) was, after stirring for $1 \mathrm{~h}$, added drop-wise under vigorous stirring. The resulting solution was stirred for $1 \mathrm{~h}$, and was then placed in a Teflon autoclave for crystallization at $160^{\circ} \mathrm{C}$ for $18 \mathrm{~h}$. The products were collected by centrifugation, washing, drying, and calcination at $500{ }^{\circ} \mathrm{C}$ for $5 \mathrm{~h}$. The nitridation of the TS- 1 supports was performed with a procedure similar to that described in our previous study [16]. The parent TS- 1 powder ( $3.5 \mathrm{~g}$ ) was placed in a quartz glass boat and inserted into a quartz tube furnace. The temperature of the furnace was increased at a ramp rate of $3{ }^{\circ} \mathrm{C} / \mathrm{min}$ to $800{ }^{\circ} \mathrm{C}$ under $\mathrm{N}_{2}$ atmosphere $(80 \mathrm{ml} / \mathrm{min})$ and maintained for a given number of hours $(3,10$, or $20 \mathrm{~h})$ under a $\mathrm{NH}_{3}$ atmosphere $(60 \mathrm{ml} / \mathrm{min})$. Finally, the furnace was cooled to $80{ }^{\circ} \mathrm{C}$ and purged again with $\mathrm{N}_{2}$ (80 $\mathrm{ml} / \mathrm{min}$ ) for $0.5 \mathrm{~h}$ to remove physically adsorbed $\mathrm{NH}_{3}$ species. The nitridized TS-1 zeolites were designated as NTS-1- $t$ ( $t$ represents the time of nitridation).

The $\mathrm{Au}$ catalyst was prepared by the DP method [11]. $\mathrm{HAuCl}_{4} \cdot \mathrm{H}_{2} \mathrm{O}$ solution ( $100 \mathrm{~g}$ of $0.5 \mathrm{mg} / \mathrm{ml}$ ) was heated to $70{ }^{\circ} \mathrm{C}$ under vigorous stirring, and the $\mathrm{pH}$ value was adjusted to 7.0 by addition of aqueous $\mathrm{NaOH}$ solution. Then $1.0 \mathrm{~g}$ of support was added and the suspension was aged at $70{ }^{\circ} \mathrm{C}$ for $1 \mathrm{~h}$. The resulting solid was collected by filtration, washed with $50 \mathrm{ml}$ of deionized water, and vacuum dried at room temperature (RT) overnight. Catalysts were labeled as Au wt $\%$ Au/ NTS-1-t.

\subsection{Characterizations}

XRD measurements were carried out with a Panalytical X'Pert PRO powder diffractometer using $\mathrm{Cu} K_{a}$ radiation $(40 \mathrm{kV}$, $30 \mathrm{~mA}$ ). DRUV-Vis spectra were recorded with a TU-1901 spectrometer. Brunauer-Emmett-Teller (BET) specific surface areas were obtained on a SSA 4200 apparatus. TEM images were acquired using a Tecnai G ${ }^{2}$ F20 electron microscope (FEI Company) operated at $200 \mathrm{kV}$. The chemical composition of the samples was determined by ICP-OES analysis (Perkin-Elmer Optima DV 2000) and carbon, hydrogen, and nitrogen analysis (Carlo Erba 1106 CHN Elemental Analyzer). XPS spectra were obtained with a Thermo VG MultiLab 2000 X-ray photoelectron spectrometer using $\mathrm{Mg} K_{\alpha}$ radiation as the excitation source.

\subsection{Catalyst evaluation}

Epoxidation of propylene was carried out in a $6 \mathrm{~mm}$ diameter tubular quartz microreactor equipped with an axial quartz-sheathed thermocouple using $0.3 \mathrm{~g}$ of catalyst. The catalyst was heated from RT to reaction temperature in $4 \mathrm{~h}$ in the reaction gas mixture and then submitted to a four-leg temperature cycle consisting of $5.5 \mathrm{~h}$ at $150{ }^{\circ} \mathrm{C}$, followed by $3.5 \mathrm{~h}$ at 170,130 , and $150{ }^{\circ} \mathrm{C}$ separated by $0.5 \mathrm{~h}$ of temperature ramping. The mixture consisted of $10 \% \mathrm{O}_{2}, 10 \% \mathrm{H}_{2}$, and $70 \% \mathrm{~N}_{2}$ with a total flow of $35 \mathrm{ml} / \mathrm{min}$. The products were analyzed online using a GC 7900 gas chromatograph equipped with a TCD (Porapak Q column) and a FID (SE-30 capillary column).

\section{Results and discussion}

\subsection{Physicochemical properties of nitrogen-incorporated TS-1}

The nitridized TS-1 supports have been shown to maintain a typical MFI structure by XRD (Fig. 1) [15,16]. TEM images (Fig. 2) also indicated that the crystalline MFI structure and shape of the support particles were maintained even after nitridation at high temperature. The tetrahedrally coordinated isolated Ti(IV) framework was evidenced by strong absorption peaks at 203$220 \mathrm{~nm}$ in the DRUV-Vis spectra (Fig. 3). The absence of an absorption band at $300-370 \mathrm{~nm}$ confirms that no anatase is present in these samples $[12,18]$. Compared with the parent TS-1, the specific surface areas and the micropore volumes of

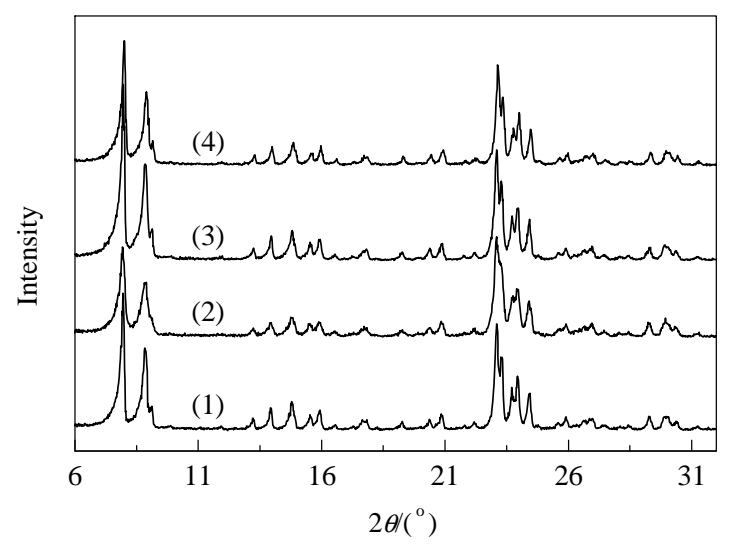

Fig. 1. XRD patterns of TS-1 and the N-incorporated TS-1. (1) Parent TS-1; (2) NTS-1-3; (3) NTS-1-10; (4) NTS-1-20. 


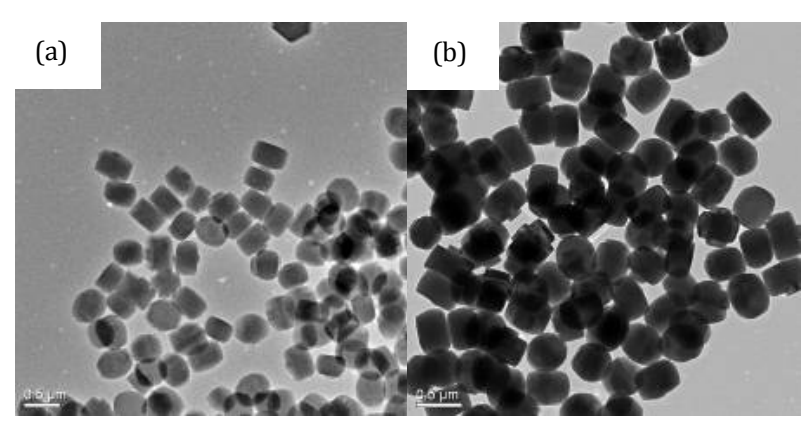

Fig. 2. TEM images of $0.03 \% \mathrm{Au} / \mathrm{TS}-1$ (a) and $0.08 \% \mathrm{Au} / \mathrm{NTS}-1-10$ (b) after reaction.

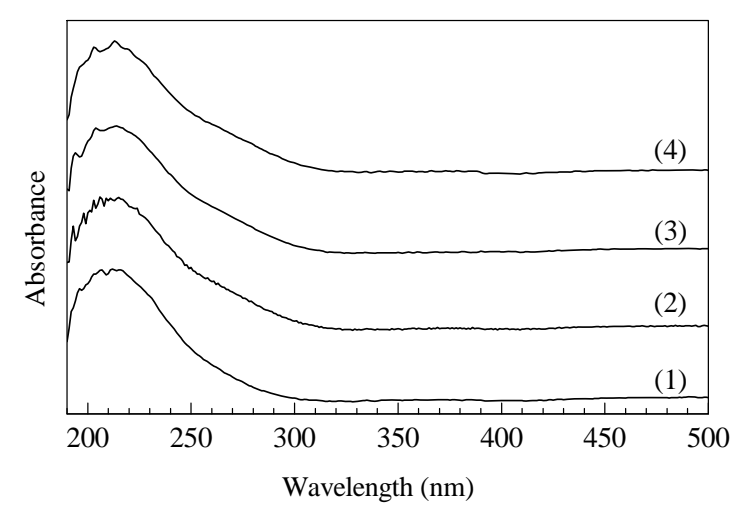

Fig. 3. DRUV-Vis spectra of TS-1 and nitrogen-incorporated TS-1 samples. (1) TS-1; (2) NTS-1-3; (3) NTS-1-10; (4) NTS-1-20.

nitridized samples changed little upon nitridation (Table 1), indicating that the pore structure was well preserved after the high temperature treatment $[15,16]$.

The presence of $-\mathrm{NH}_{2}$ and $-\mathrm{NH}$ - species in NTS-1, confirmed by XPS (Fig. 4) and ${ }^{29} \mathrm{Si}$ magic angle spinning nuclear magnetic resonance (MAS NMR), and the temperature-programmed desorption of ammonia ( $\mathrm{NH}_{3}$-TPD) clearly indicated that the acidity of the TS-1 zeolite decreased after nitridation $[15,16]$. The titanium content of the TS- 1 and the nitridized samples determined by ICP-OES analysis remained constant (1.02 wt\%). The results, shown in Table 2, indicate that $\mathrm{NH}_{3}$ treatment of the TS- 1 support increased the Au capture efficiency by more than a factor of two when compared with the untreated support materials under the same $\mathrm{HAuCl}_{4} \cdot 4 \mathrm{H}_{2} \mathrm{O}$ concentration. Moreover, the Au capture efficiency quickly increased with increasing $\mathrm{HAuCl}_{4} \cdot 4 \mathrm{H}_{2} \mathrm{O}$ concentration. HRTEM images (Fig. 5) distinctly indicated that $\mathrm{NH}_{3}$ treatment of the TS-1 support had a significant beneficial effect for obtaining smaller and more uniform GNPs (2-4 $\mathrm{nm}$ ) on the support surface. Lee et al. [19] assumed
Table 1

Properties of TS-1 and N-incorporated TS-1 samples.

\begin{tabular}{lcc}
\hline Support & Specific surface area $\left(\mathrm{m}^{2} / \mathrm{g}\right)$ & Volume $\left(\mathrm{cm}^{3} / \mathrm{g}\right)$ \\
\hline TS-1 & 471 & 0.265 \\
NTS-1-3 & 445 & 0.269 \\
NTS-1-10 & 499 & 0.277 \\
NTS-1-20 & 467 & 0.261 \\
\hline
\end{tabular}

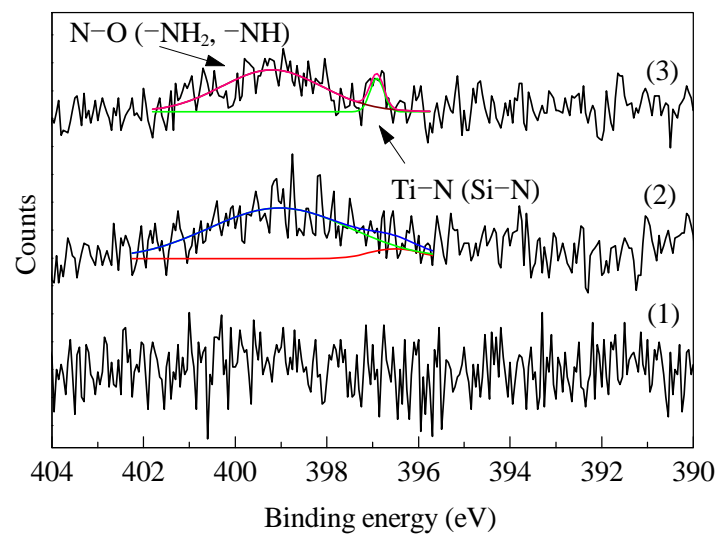

Fig. 4. XPS profiles of parent TS-1 (1), NTS-1-3 (2), and NTS-1-10 (3) samples.

that very small GNPs, which are not visible in TEM, can contribute significantly to the activity of the Au/TS-1 catalyst. Therefore, the average diameter of GNPs visible in TEM is not very important for Au/TS-1. The high homogeneous dispersion of GNPs on NTS-1 was further verified by the FFT image (Fig. 5 inset). Taken together, these results indicate that the nitrogen-incorporated TS-1 improved both the Au capture efficiency and dispersion.

\subsection{Catalytic performance for propylene epoxidation}

The PO activity of the various Au catalysts was obtained after $5.5 \mathrm{~h}$ reaction at $150{ }^{\circ} \mathrm{C}$ (Table 2 ). The main products in this reaction consist of $\mathrm{CO}_{2}, \mathrm{H}_{2} \mathrm{O}$, and $\mathrm{C} 3$ compounds such as $\mathrm{PO}$ and acetone. The $\mathrm{Au}$ catalysts supported on $\mathrm{NH}_{3}$-treated $\mathrm{TS}-1$ have shown greatly enhanced catalytic activity for propylene epoxidation compared with untreated catalysts (Table 2). The catalytic activity of Au/NTS- 1 was clearly dependent on the $\mathrm{NH}_{3}$ treatment time, as shown in Table 2. However, further prolonging the nitridation time to $20 \mathrm{~h}$ resulted in a decrease of the catalytic activity. The most reactive catalyst, $0.08 \% \mathrm{Au} / \mathrm{NTS}-1-10$, gave a propylene conversion of $6.8 \%$ and a PO selectivity of $84.4 \%$, corresponding to a PO formation rate

Table 2

Propylene epoxidation over $\mathrm{Au} /(\mathrm{N}) \mathrm{TS}-1$ catalysts prepared under various conditions.

\begin{tabular}{|c|c|c|c|c|c|c|c|c|}
\hline \multirow{2}{*}{ Catalyst } & \multicolumn{2}{|c|}{ Loading (wt\%) } & \multirow{2}{*}{$\begin{array}{c}\text { Au capture } \\
\text { efficiency (\%) }\end{array}$} & \multirow{2}{*}{$X\left(\mathrm{C}_{3} \mathrm{H}_{6}\right) / \%$} & \multirow{2}{*}{$S(\mathrm{PO}) / \%$} & \multirow{2}{*}{$S$ (acetone) $/ \%$} & \multirow{2}{*}{$S\left(\mathrm{CO}_{2}\right) / \%$} & \multirow{2}{*}{$r(\mathrm{PO}) /\left(\mathrm{g}_{\mathrm{PO}} /\left(\mathrm{h} \cdot \mathrm{kg}_{\mathrm{cat}}\right)\right)$} \\
\hline & $\mathrm{Au}^{\mathrm{a}}$ & $\mathrm{N}^{\mathrm{b}}$ & & & & & & \\
\hline $0.03 \% \mathrm{Au} / \mathrm{TS}-1$ & 0.03 & 0.00 & 1.25 & 2.7 & 89.4 & 4.9 & 5.7 & 43.9 \\
\hline $0.07 \% \mathrm{Au} / \mathrm{NTS}-1-3$ & 0.07 & 0.31 & 2.93 & 4.7 & 89.3 & 3.8 & 6.9 & 76.0 \\
\hline $0.08 \% \mathrm{Au} / \mathrm{NTS}-1-10$ & 0.08 & 0.34 & 3.35 & 6.8 & 84.4 & 4.9 & 10.7 & 104.5 \\
\hline $0.06 \% \mathrm{Au} / \mathrm{NTS}-1-20$ & 0.06 & 0.37 & 2.51 & 5.4 & 88.3 & 3.4 & 8.3 & 85.8 \\
\hline
\end{tabular}

Reaction conditions: $\mathrm{C}_{3} \mathrm{H}_{6} / \mathrm{H}_{2} / \mathrm{O}_{2} / \mathrm{N}_{2}=3.5 / 3.5 / 3.5 / 24.5 \mathrm{ml} / \mathrm{min}$, space velocity $=7000 \mathrm{ml} /\left(\mathrm{h} \cdot \mathrm{g}_{\text {cat }}\right.$ ), reaction temperature $=150{ }^{\circ} \mathrm{C}$.

a Determined by ICP-OES. ${ }^{\text {b }}$ Determined by CHN analyses. PO-Propylene oxide. 

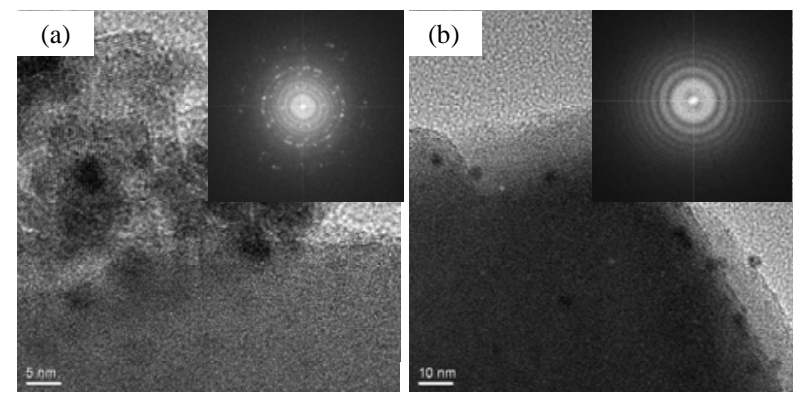

Fig. 5. HRTEM and FFT (inset) micrographs of $0.03 \mathrm{Au} / \mathrm{TS}-1$ (a) and 0.08Au/NTS-1-10 (b) after reaction.

of $104.5 \mathrm{~g}_{\mathrm{PO}} /\left(\mathrm{h} \cdot \mathrm{kg}_{\mathrm{cat}}\right)$. This is a greater than 2 -fold enhancement compared with the untreated $0.03 \% \mathrm{Au} / \mathrm{TS}-1$ catalyst. Enhanced propylene conversion and PO selectivity can be attributed to the nitrogen-incorporation, which improved both gold loading and dispersion. Lu et al. [18] found that a Mg-promoted catalyst gave a 50\% enhancement of activity because of increased Au capture efficiency and dispersion.

Propylene conversion decreased with the on-stream time in many cases, but a smaller relative decrease was observed for the $\mathrm{N}$-incorporated catalysts (Fig. 6). The PO selectivity of each catalyst slightly increased during the reaction (Table 3 ). The deactivation is probably caused by two factors: (1) aggregation of $\mathrm{Au}$ particles and (2) deposition of products on the catalyst surface. Because the $0.08 \% \mathrm{Au} / \mathrm{NTS}-1-10$ catalyst did not show obvious aggregation after reaction, the former possibility seems not to act in a substantial way (Fig. 5(b)). The deactivation of the $0.08 \% \mathrm{Au} / \mathrm{NTS}-1-10$ is mainly because of deposition of products on the catalyst surface, which may be polymeric species or bidentate propoxy species [20]. In our case, the deactivation is slight because the strong coordination capability of the terminal $\mathrm{NH}_{2}$ ligands on the support surface improved gold dispersion and inhibited the aggregation of Au particles (Fig. 5).

\subsection{Role of $\mathrm{NH}_{3}$ treatment of TS-1 support}

The role of $\mathrm{NH}_{3}$-treatment of the TS-1 support on enhancing $\mathrm{Au}$ capture and activity is speculated. Formation of terminal $\mathrm{NH}_{2}$ groups was the dominant nitridation outcome under our

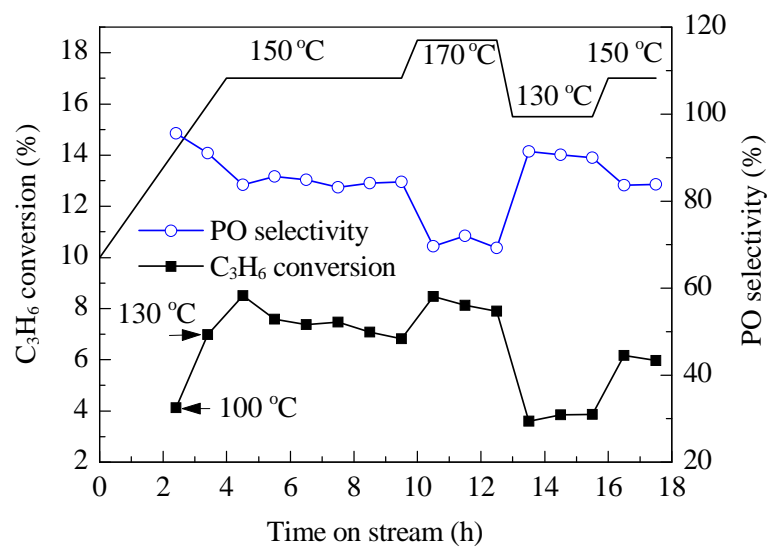

Fig. 6. Catalytic performance of $0.08 \mathrm{Au} / \mathrm{NTS}-1-10$ catalyst with time on stream.
Table 3

Propylene epoxidation over $\mathrm{Au} /(\mathrm{N}) \mathrm{TS}-1$ catalysts.

\begin{tabular}{lccccc}
\hline \multirow{2}{*}{ Catalyst } & \multicolumn{2}{c}{$\mathrm{X}\left(\mathrm{C}_{3} \mathrm{H}_{6}\right) / \%$} & & \multicolumn{2}{c}{$S(\mathrm{PO}) / \%$} \\
\cline { 2 - 3 } \cline { 5 - 6 } & $0.5 \mathrm{~h}$ & $5.5 \mathrm{~h}$ & & $0.5 \mathrm{~h}$ & $5.5 \mathrm{~h}$ \\
\hline $0.03 \% \mathrm{Au} / \mathrm{TS}-1$ & 3.6 & 2.7 & & 86.6 & 89.4 \\
$0.07 \% \mathrm{Au} / \mathrm{NTS}-1-3$ & 5.7 & 4.7 & & 88.9 & 89.3 \\
$0.08 \% \mathrm{Au} / \mathrm{NTS}-1-10$ & 8.5 & 6.8 & & 83.8 & 84.4 \\
$0.06 \% \mathrm{Au} / \mathrm{NTS}-1-20$ & 6.7 & 5.4 & & 87.7 & 88.3 \\
\hline Reaction conditions: $\mathrm{C}_{3} \mathrm{H}_{6} / \mathrm{H}_{2} / \mathrm{O}_{2} / \mathrm{N}_{2}=3.5 / 3.5 / 3.5 / 24.5 \mathrm{ml} / \mathrm{min}, \mathrm{space}$ \\
velocity = 7000 ml/(h.g $\left.\mathrm{g}_{\text {cat }}\right), 150{ }^{\circ} \mathrm{C}$.
\end{tabular}

experimental conditions [16,21]. With increasing nitridation time, the nitrogen content of the nitridized samples increases (Table 2). Compared with the parent materials, the acid strength of the modified TS- 1 support was decreased, which was supported by $\mathrm{NH}_{3}$-TPD results $[15,16]$ and the change of $\mathrm{pH}$ after adding the support in the DP process. The $\mathrm{pH}$ increased from 7.0 to $7.8-8.3$ after adding the $N$-incorporated support. The deposition of PO on the support surface was depressed, which inhibited deactivation of the catalyst surface by the formation of oligomerized species from adsorbed PO at these sites. As a result, the PO selectivity of the catalyst slightly increased during the reaction (Table 3). Haruta et al. [8] found that elimination of surface acidic sites improved the catalyst stability. The formation of an Au-amine complex next to the Ti sites served not only to increase Au capture but also to enhance the homogeneous dispersion of gold on the TS-1 support [12]. With increased nitridation time, the concomitant formation of -NH- species through condensation between the $\mathrm{Si}-\mathrm{NH}_{2}$ and $\mathrm{T}-\mathrm{OH}(\mathrm{T}=\mathrm{Si}$ or $\mathrm{Ti})$ species could occur. The performance of the $0.06 \% \mathrm{Au} / \mathrm{NTS}-1-20$ catalysts clearly suggests that this $-\mathrm{NH}-$ species was detrimental to catalyst performance and Au capture (Table 2). The Au capture increase is likely to be because of the ligand effect of the terminal- $\mathrm{NH}_{2}$ on the NTS-1. Furthermore, thermal treatment by ammonia resulted in oxygen vacancies and N-related defects [22], which have been shown to have a positive influence on PO yield [14,23]. Further investigations are needed to determine the reason that $\mathrm{NH}_{3}$-treatment of TS-1 supports enhances Au capture and activity.

\section{Conclusions}

Excellent supports for GNPs could be obtained by ammonia treatment of TS-1 supports at elevated temperatures. Nitrogen-incorporated TS-1 decreased the acidic sites of support surface. The terminal $\mathrm{NH}_{2}$ ligands improved both gold loading and dispersion, and improved the catalytic performance remarkably. Our gold catalysts have great potential for future improvement by optimization of the gold nanoparticle size, the gold content, the nitrogen content, and the isolated Ti sites.

\section{References}

[1] Stephen A, Hashmi K. Angew Chem, Int Ed, 2006, 45: 7896

[2] Nijhuis T A, Makkee M, Moulijn J A, Weckhuysen B M. Ind Eng Chem Res, 2006, 45: 3447

[3] Dai M H, Tang D L, Yuan Y Zh. Chin J Catal (戴茂华, 汤丁亮, 袁友 珠. 催化学报), 2006, 27: 1063 


\title{
Graphical Abstract
}

Chin. J. Catal., 2013, 34: 336-340 doi: 10.1016/S1872-2067(11)60474-9

\section{Gold supported on nitrogen-incorporated TS-1 for gas-phase epoxidation of propylene}

LIU Yiwu, ZHANG Xiaoming*, SUO Jishuan

Chengdu Institute of Organic Chemistry, Chinese Academy of Sciences; Neijiang Normal University

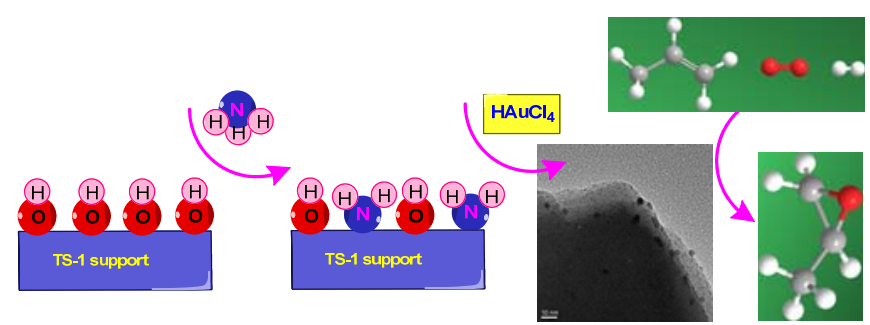

A novel gold catalyst was prepared by immobilization of gold nanoparticles on nitrogen-incorporated TS-1. This catalyst exhibits an excellent catalytic capacity for gas-phase epoxidation of propylene using $\mathrm{H}_{2}$ and $\mathrm{O}_{2}$. Nitrogen-incorporation into TS- 1 improved both gold loading and dispersion, and decreased the acidic sites of the support surface.

[4] Fang X Q, Wang Y N, Deng X J, Wu H H, Wu P, Liu Y M, He M Y. Chin J Catal (方向青, 王钰宁, 邓秀娟, 吴海虹, 吴鹏, 刘月明, 何鸣元. 催化学报), 2011, 32: 333

[5] Oyama S T, Zhang X M, Lu J Q, Gu Y F, Fujitani T. J Catal, 2008, 257 . 1

[6] Qi C X, Akita T, Okumura M, Kuraoka K, Haruta M. Appl Catal A, 2003, 253: 75

[7] Sinha A K, Seelan S, Tsubota S, Haruta M. Angew Chem, Int Ed, 2004, 43: 1546

[8] Chowdhury B, Bravo-Suarez J J, Date M, Tsubota S, Haruta M. Angew Chem, Int Ed, 2006, 45: 412

[9] Yang H W, Tang D L, Lu X N, Yuan Y Z.J Phys Chem C, 2009, 113: 8186

[10] Liu T, Hacarlioglu P, Oyama S T, Luo M F, Pan X R, Lu J Q. J Catal, 2009, 267: 202

[11] Liu Y W, Yu H, Zhang X M, Suo J S. Acta Phys-Chim Sin (刘义武, 余 欢, 张小明, 索继栓. 物理化学学报), 2010, 26: 1585

[12] Cumaranatunge L, Delgass W N. J Catal, 2005, 232: 38

[13] Sacaliuc-Parvulescu E, Friedrich H, Palkovits R, Weckhuysen B M,
Nijhuis T A. J Catal, 2008, 259: 43

[14] Huang J H, Takei T, Akita T, Ohashi H, Haruta M. Appl Catal B, 2010, 95: 430

[15] Li H, Lei Q, Zhang X M, Suo J S. ChemCatChem, 2011, 3: 143

[16] Li H, Lei Q Zhang X M, Suo J S. Microporous Mesoporous Mater, 2012, 147: 110

[17] Khomane R B, Kulkarni B D, Paraskar A, Sainkar S R. Mater Chem Phys, 2002, 76: 99

[18] Lu J Q, Zhang X M, Bravo-Suarez J J, Fujitani T, Oyama S T. Catal Today, 2009, 147: 186

[19] Lee W S, Akatay M C, Stach E A, Ribeiro F H, Delgass W N. J Catal, 2012, 287: 178.

[20] Mul G, Zwijnenburg A, van der Linden B, Makkee M, Moulijn J A. J Catal, 2001, 201: 128.

[21] Wu G J, Guan N J, Li L D. Chin J Catal (武光军, 关乃佳, 李兰冬. 催 化学报), 2012, 33: 51

[22] Chino N, Okubo T. Microporous Mesoporous Mater, 2005, 87: 15

[23] Wells D H, Delgass W N, Thomson K T. J Am Chem Soc, 2004, 126: 2956

\section{Au/NTS-1 催化丙烯气相直接环氧化}

\author{
刘义武, ${ }^{\mathrm{a}, \mathrm{b}}$, 张小明 ${ }^{\mathrm{a},{ }^{*}}$, 索继栓 ${ }^{\mathrm{a}}$ \\ $\mathrm{a}$ 中国科学院成都有机化学研究所, 四川成都 610041 \\ b内江师范学院化学化工学院, 四川内江 641100
}

摘要: 以高温氨气处理制得含氮微孔钛硅分子笁(NTS-1) 为载体, 用沉积-沉淀法制得了一系列纳米金催化剂. 考察了纳米金催化 剂在氢气和氧气共存下催化丙烯气相环氧化制环氧丙烷反应中的催化性能. 结果表明, 高温氨气处理钛硅分子篮(TS-1)载体降低 了其酸性, 提高了纳米金催化剂制备中金的利用率和纳米金催化剂中金的分散度,显著提高纳米金催化剂的催化活性. 载体酸性 降低和载体表面 $-\mathrm{NH}_{2}$ 配位效应增强了催化剂活性.

关键词: 金; 含氮钛硅分子笁; 环氧化; 氮化; 环氧丙烷; 钛硅分子笁相

收稿日期: 2012-09-21. 接受日期: 2012-10-24. 出版日期: 2013-02-20.

*通讯联系人. 电话: (028)85226215; 传真: (028)85223978; 电子信箱: xm.zhang@cioc.ac.cn

基金来源: 国家自然科学基金 (20703039).

本文的英文电子版由Elsevier出版社在ScienceDirect上出版(http://www.sciencedirect.com/science/journal/18722067). 